\title{
Management of Depressed Skull Fractures: Selective Conservative Management of Non Missile Injuries
}

\author{
SAFDAR HUSSAIN ARAIN ${ }^{1}$, MUHAMMAD ASLAM SHAIKH ${ }^{2}$, MUMTAZ ALI NAREJO ${ }^{3}$, NAJMUS SAQIB ANSARI ${ }^{4}$, ABDUL \\ RAZAQUE MARI ${ }^{5}$ \\ ${ }^{1}$ Associate Professor \& Head, Department of Neurosurgery, Pir Abdul Qadir Shah Jeelani Institute of Medical Sciences, Gambat \\ ${ }^{2}$ Associate Professor \& Chairperson, Department of Neurosurgery, Chandka Medical College, Shaheed Mohtarma Benazir Bhutto Medical \\ University, Larkana \\ ${ }^{3}$ Assistant Professor, Department of Neurosurgery, Pir Abdul Qadir Shah Jeelani Institute of Medical Sciences, Gambat \\ ${ }^{4}$ Assistant Professor, Department of Neurosurgery, Ghulam Muhammad Mahar Medical College Sukkur \\ ${ }^{5}$ Associate Professor, Department of Neurosurgery, People's University of Medical \& Health Sciences, Nawabshah \\ Correspondence to: Dr. Safdar Hussain Arain, E-mail: drsafdararain@gmail.com, Cell 0321-2318923
}

\begin{abstract}
Objective: To determine the outcomes of management of depressed skull fractures.

Study Design: Descriptive Study

Place and Duration of Study: Department of Neurosurgeries, Pir Abdul Qadir Shah Jeelani Institute of Medical Sciences Gambat and Chandka Medical College Hospital, Larkana from $1^{\text {st }}$ March 2020 to $28^{\text {th }}$ February 2021. Methodology: Eighty patients of both sexes were enrolled in this study. Patients were aged between 12-70 years of age. Patient's detailed demographics age, sex and body mass index were recorded. Diagnosis of skull fractures from closed head injury patients were undergone for CT scan Depressed fracture of more than $5 \mathrm{~mm}$, cosmetically disfiguring fractures and fracture over the sinuses were operated. All the patients were given prophylactic antibiotics and anticonvulsants. Patients were followed for 4-months. Outcomes were assessed by Glasgow Coma Scale (GCS).

Results: Fifty five $(68.8 \%)$ patients were males and thirty five $(31.2 \%)$ were females with mean age was $18.21 \pm 7.32$ years and mean body mass index was $20.04 \pm 3.14 \mathrm{~kg} / \mathrm{m}^{2}$. Road traffic accident $(56.25 \%)$ was the most common cause of the injury followed by fall from the height $25(31.25 \%)$. The compound fractures have 48 $(60 \%)$ and simple fractures were $32(40 \%)$. Surgery was done among $70(87.5 \%)$ cases and $10(12.5 \%)$ patients were conservatively treated. Among these $50(62.5 \%)$ patients were completely recovered. Cerebrospinal fluid leak was the most common complication and was found in $13(16.25 \%)$ cases.

Conclusion: The use of antibiotics and anticonvulsants had effective results during peri-operative periods to avoid infection and epilepsy. The initial stage of operation is particularly necessary when the fracture is larger than $5 \mathrm{~mm}$. Cerebrospinal fluid leaks occur after surgery as the most common complication.

Keywords: Depressed skull fracture, Non-missile injuries, Cerebrospinal fluid
\end{abstract}

\section{INTRODUCTION}

Nearly half of the deaths from trauma are due to head injury. ${ }^{1}$ Around $2,000,000$ head injuries occur annually in the USA and as many as 56,000 deaths annually. ${ }^{2}$ Depressed skull fractures are fractures in which shattered bones are displaced to the inside, a very hazardous type of trauma occurring with $11 \%$ of severe head injuries. ${ }^{3}$ This form of fracture is likely to increase pressure on the brain to crush the sensitive tissues. Approximately $25 \%$ of skull fractures are complex and should be considered immediately. ${ }^{4}$ Complex depression fractures are the ones that tear the hard substance.

Etiology is frequently post-traumatic after falls or road accidents. ${ }^{5} 25 \%$ of patients with depressed skull breaks report a loss of consciousness for less than an hour and a further $25 \%$ describe loose awareness. The presentation can vary according to various related injuries, such as underlying hematoma, dural rupture, contusions in the brain and seizures. ${ }^{6}$ Dural rip with concomitant underlying brain damage has been documented varyingly in patients with depressed skull fractures. ${ }^{7,8} \mathrm{X}$-rays skull and CT scan heads are important research techniques to demonstrate fracture, type, position, depression, and cerebral injury. ${ }^{9}$

Depressed skull fractures will be treated depending on their degree of depression, external communication and neurological impairments. Operating indications in depressed skull fractures include: complex depressed fractures, cerebrospinal fluid leaking, depression more than the inner side of the non-depressed bone, local neurological deficits induced by pressure of a depressed fragment, related lesions other than the underlying blood pressure, and the presence on the head of a depressed fracture for cosmetic reasons. ${ }^{10}$

The purpose of this study was to assess the results of conservatively treated depressed skull fractures.

\section{MATERIALS AND METHODS}

This descriptive study was conducted at Department of Neurosurgeries, Pir Abdul Qadir Shah Jeelani Institute of Medical Sciences, Gambat and Chandka Medical College Hospital, Larkana from $1^{\text {st }}$ March 2020 to $28^{\text {th }}$ February 2021 and comprised 80 patients. Patient's details demographics were recorded and age between 12-70 years. Patients did not have depressed skull fracture and below than 12 years were excluded. Causes of depressed skull fracture, duration since injury, clinical condition and CT scan findings were recorded. CT Scans were done in all cases. Depressed fracture of more than $5 \mathrm{~mm}$, cosmetically disfiguring fractures and fracture over the sinuses were surgically managed.

Surgical procedures include; $S$ shaped, linear or horse shoe flap incisions according to type and site of 
depressed skull fractures, elevation of depressed bone fragment, removal of in driven bone fragment, repair of dural tear, evacuation of hematoma, homeostasis, debridement of wound margin and primary repair. Antibiotics and anticonvulsants were given to the patients. Patients were followed for 4-months and outcomes were assessed by GCS. Complete data was analyzed by SPSS24.

\section{RESULTS}

Fifty five (68.8\%) patients were males and $25(31.2 \%)$ were females. Patients mean age was $18.21 \pm 7.32$ years with mean BMI $20.04 \pm 3.14 \mathrm{~kg} / \mathrm{m}^{2}$. Road traffic accident $(56.3 \%)$ was the most common cause of the injury followed by fall from the height 25 (31.3\%).Frequency of compound fracture was $48(60 \%)$ and simple fractures were $32(40 \%)$ [Table 1]. Most of the affected region was temporal 45 (56.3\%), frontal region found in $17(21.3 \%)$, parietal region in $12(15 \%)$, occipital region in $3(3.7 \%)$ and other regions 3 (3.7\%) [Table 2].

The surgery was done among $70(87.5 \%)$ cases and $10(12.5 \%)$ patients were conservatively treated. Among these $50(62.5 \%)$ patients were completely recovered. While frequency of moderate disability was 15 (18.75\%), severe disability found in $9(11.25 \%)$ and wound infection developed in $6(7.5 \%)$ [Table 3]. Cerebrospinal fluid leaks was the most common complication and was found in 13 (39.4\%) cases followed by bleeding $9(27.3 \%)$, meningitis found in $6(18.2 \%)$ and loss of consciousness was in 5 (15.1\%) [Table 4].

Table 1: Demographically details on presented cases

\begin{tabular}{|l|l|l|}
\hline Variable & No. & $\%$ \\
\hline Gender & 55 & 68.8 \\
\hline Male & 25 & 31.2 \\
\hline Female & $18.21 \pm 7.32$ \\
\hline Mean age (years) & $20.04 \pm 3.14$ \\
\hline Mean BMI (kg/m $\left.{ }^{2}\right)$ & \multicolumn{2}{|l|}{} \\
\hline Types of fracture & 48 & 60.0 \\
\hline Compound & 32 & 40.0 \\
\hline Simple & \multicolumn{2}{|l|}{} \\
\hline Causes of fracture & 45 & 56.3 \\
\hline RTA & 25 & 31.3 \\
\hline Fall from height & 10 & 12.5 \\
\hline Assaults and others &
\end{tabular}

Table 2: Effected regions of depressed skull fractures $(n=80)$

\begin{tabular}{|l|l|l|}
\hline Effected regions & No. & $\%$ \\
\hline Temporal & 45 & 56.3 \\
\hline Frontal & 17 & 21.3 \\
\hline Parietal & 12 & 15.0 \\
\hline Occipital & 3 & 3.7 \\
\hline Other regions & 3 & 3.7 \\
\hline
\end{tabular}

Table 3: Frequency of outcome presented with GCS ( $\mathrm{n}=80)$

\begin{tabular}{|l|l|l|}
\hline Outcome & No. & $\%$ \\
\hline Operated & 70 & 87.5 \\
\hline Conservatively treated & 10 & 12.5 \\
\hline GCS Outcomes & \multicolumn{2}{|l|}{} \\
\hline Completely recovered & 50 & 62.5 \\
\hline Moderate (Disability) & 15 & 18.75 \\
\hline Severe (Disability) & 9 & 11.25 \\
\hline Wound developed & 6 & 7.5 \\
\hline
\end{tabular}

Table 4: Postoperatively complications among patients $(n=33)$

\begin{tabular}{|l|l|l|}
\hline Complication & No. & $\%$ \\
\hline CSF leaks & 13 & 39.4 \\
\hline Nose bleeding & 9 & 27.3 \\
\hline Meningitis & 6 & 18.2 \\
\hline Loss of consciousness & 5 & 15.1 \\
\hline
\end{tabular}

\section{DISCUSSION}

Globally, head injuries remain an important public health problem and contribute significantly to high morbidity, mortality and long term disability. ${ }^{11}$ In the present study, patients were aged between 12-70 years and majority of patients were between 5 to 15 years. This result showed similarity to the study by Mushtaq et $\mathrm{al}^{12}$, in their study most common age group was 5 to 16 years.

In the current study, fifty five $(68.8 \%)$ patients were male and thirty five $(31.2 \%)$ were females. Road traffic accident $(56.25 \%)$ was the most common cause of the injury followed by fall from the height 25 (31.25\%). Many of previous studies reported male patients were predominant and road traffic accidents were the major cause of depressed skull fractures followed by fall from height. ${ }^{13,14}$ Two factors typically influence the pattern of skull fracture. The first element is the impact force. The other aspect is the impact ratio. The impact rate even if scattered in wide areas by high energy, as in the case of a head injury to an individual who is wearing a motorcycle helmet, sometimes does not produce a skull fracture.

The major head injury in developing countries is a major issue in the intracranial injury. In the young population, it can be fatal. ${ }^{15,16}$ The treatment of these patients can be carried out using both conservative and surgical approaches according to cosmetics and the practical In our study frequency of compound fracture was $48(60 \%)$ and simple fractures were $32(40 \%)$. Surgery was done among $70(87.5 \%)$ cases and $10(12.5 \%)$ patients were conservatively treated. Among these 50 (62.5\%) patients were completely recovered. The relationship between GCS arrival and last functional result was positive in our research. These results are similar to previous studies. ${ }^{16}$ Studies have shown that GCS is a strong predictor of GOS performance. ${ }^{17,18}$ These are also good tools for evaluating the original neurological condition and the eventual outcome.

This study showed that $62.5 \%$ patients were fully recovered while frequency of moderate disability was 15 (18.75\%), severe disability found in $9(11.25 \%)$ and wound infection developed in 6 (7.5\%). A study conducted by Asif et $\mathrm{al}^{19}$ in which they operated 100 patients of depressed skull fractures and they reported $55 \%$ had GCS $13-15$.

Ali and $\mathrm{Ali}^{20}$ have confirmed focal deficit in $14 \%$ and $9 \%$ had CSF leaks, $7 \%$ had extradural haematoma, and $15 \%$ of patients had gross Skull Deformation in a 7 -year study of 98 cases of depressed fractures. The indications of emergence from surgical elevations of depressed skull fractures are also identified as the clinical and radiological features. In most cases, GCS patients have persistently increased ICP either because of a localized intracraneal or parenchymal lesion or because they have diffuse brain oedema. Urgent exploration, debridging, and elevation of depressed fracturing can be desired due to a variety of reasons and these include surgical debridement of infected 
injury, uplifting depressed-kidney segment of the skull, removal or resection of an acute extradural or subdural haematoma, hard repair in cases where the dural tear is not present.

Cerebrospinal fluid leaks was the most common complication and was found in $13(16.25 \%)$ cases followed by bleeding $9(11.25 \%)$, meningitis found in $6(7.5 \%)$ and loss of consciousness was in 5 (6.25\%). Following surgical management, this rate of complication of CSF is comparable to many of previous studies in which CSF was documented in 25 to $40 \%$ patients followed by loss of consciousness. ${ }^{21,22}$

\section{CONCLUSION}

The depressed cranial fracture was most commonly observed in teen ages. The use of antibiotics and anticonvulsants had effective results during peri-operative periods to avoid infection and epilepsy. The initial stage of operation is particularly necessary when the fracture is larger than $5 \mathrm{~mm}$. Cerebrospinal fluid leaks occur after surgery as the most common complication.

\section{REFERENCES}

1. Khan IU, Nadeem M. There is high incidence of skull fractures associated with extradural hamatoma in patients with head injury. Rawal Med J 2008; 33: 228-230.

2. Kraus JF, Mac Arther DL. Epidemiologic aspects of brain injury. Neurol Clin 1996; 14(2): 435-50.

3. Bullock MR, Chesnut R, Ghajar J, Gordon D, Hartl R, et al. Surgical management of Traumatic Brain Injury Author Group Surgical management of depressed cranial fractures. Neurosurgery 2006; 58: S56-60.

4. Dhandapani SS, Sarda AC, Kapoor A, Salunke P, Mathuriya $\mathrm{SN}$, et al. Validation of a New Clinico-Radiological Grading for Compound Head Injury: Implications on the Prognosis and the Need for Surgical Intervention. World Neurosurg 2015; 84: 1244-1250.

5. Heary RF, Hunt CD, Krieger AJ, Schulder M, Vaid C. Nonsurgical treatment of compound depressed skull fractures. J Trauma 1993; 35: 441-7.

6. Mukherjee KK, Dhandapani S, Sarda A, Tripathi M, Salunke $\mathrm{P}$, et al. Prospective comparison of simple suturing and elevation debridement in compound depressed fractures with no significant mass effect. Acta Neurochir (Wien) 2015; 157: 305-9.

7. Mendelow AD, Campbell D, Tsementzis SA, Cowie RA, Harris $P$, et al. Prophylactic ntimicrobial management of compound depressed skull fracture. J R Coll Surg Edinb 1983; 28: 80-83.

8. Van den Heever CM, van der Merwe DJ. Management of depressed skull fractures. Selective conservative management of nonmissile injuries. J Neurosurg 1989; 71: 186-90.

9. Nnadi MO, Bankole OB, Arigbabu SO. Outcome of surgically treated non-missile traumatic depressed skull fracture. Niger Postgrad Med J 2014;21(4):311-4.

10. Rehman L, Ghani E, Hussain A, Shah A, Noman MA, Khaleeq Z. Infection in compound depressed fracture of the skull. J Coll Physicians Surg Pak 2007;17(3):140-3.

11. Mossop D, Soysa S. The use of skull X-rays in head injury in the emergency department: a changing practice. Ann R Coll Surg Engl 2005;87:188-90.

12. Mushtaq A, Azam F, Rehman R, Khattak A, et al. Surgical management and outcome of depressed skull fracture. Pak $\mathrm{J}$ Neurol Surg 2010; 14(1): 11-5.

13. Muhammad G, Javeed F, Rehman L, Abbas A, Afzal A. Pattern of Skull Fractures and Its Outcome in Pediatric Head Injury Patients. PJNS 2020; 24(4): 350-56.

14. Ali L, Badar A. Management of Depressed Skull Fracture. J Saidu Med Coll Swat 2021;11(1): 30-33.

15. Burns EC, Grool AM, Klassen TP, Correll R, Jarvis A, Joubert G, et al. Scalp hematoma characteristics associated with intracranial injury in pediatric minor head injury. Acad Emerg Med 2016; 23(5): 576-83.

16. Al-Haddad SA, Kirollos R. A 5-year study of the out-come of surgically treated depressed skull fractures. Ann R Coll Surg Engl 2002;84(3):196-200

17. Ebtehaj M, Yaqubi S, Seddighi AS, Seddighi A, Yazdi Z. Correlation between BIS and GCS in patients suffering from head injury. Ir J Med Sci 2012;181(1):77-80.

18. van den Heever CM, van der Merwe DJ. Management of depres-sed skull fractures: selective conservative management of nonmissile injuries. $J$ Neurosurg Nurs 1989;71(2):186-90.

19. Asif M, Fatima A. Depressed skull fracture management of 100 cases at DHQ Teaching Hospital/Sahiwal Medical College Sahiwal. Pak J Neurol Surg 2017; 21(3): 144-8.

20. Ali M, Ali L, Roghani IS. Surgical management of depressed skull fracture. J Postgrad Med Inst 2003;17(1):116-23.

21. Bonfield CM, Naran S, Adetayo OA, Pollack IF, Losee JE. Pediatric skull fractures: the need for surgical intervention, characteristics, complications, and outcomes. J Neurosurg Pediatr 2014;14(2):205-11.

22. Rolekar NG. Prospective study of outcome of depressed skull. IJMSPH 2014; 3(12): 1540-44. 